\title{
Comparison of Proximate Chemical Composition and Texture of cupim, Rhomboideus $m$. and lombo, Longissimus dorsi m.of Nelore (Bos indicus)
}

\author{
Mayka Reghiany Pedrão ${ }^{1,2}$, Fernanda Lassance, ${ }^{3}$, Nilson Evelazio de Souza ${ }^{4}$, Makoto \\ Matsushita $^{4}$, Paulo Telles ${ }^{5}$ and Massami Shimokomaki ${ }^{*}$ \\ ${ }^{I}$ Departamento de Tecnologia de Alimentos e Medicamentos; Centro de Ciências Agrárias; Universidade Estadual \\ de Londrina; C. P.: 6001; 86051-990; Londrina - PR - Brasil. ${ }^{2}$ Universidade Tecnológica Federal do Paraná; Av. \\ dos Pioneiros, 3131; 86036-370; Londrina - PR - Brasil. ${ }^{3}$ Departmento de Histologia; Universidade Estadual de \\ Londrina; C. P.: 6001; 86051-970; Londrina - PR - Brasil. ${ }^{4}$ Departamento de Química; Universidade Estadual de \\ Maringá; Av. Colombo, 5790; 87.020-90; Maringá - PR - Brasil. ${ }^{5}$ Serviço Federal de Inspeção; Jataizinho - PR - \\ Brasil
}

\begin{abstract}
The proximate chemical composition of hump, known in Brazil as cupim, Rhomboideus m. (RB), of Nelore (Bos indicus) aged 24 months revealed it to be a unique beef muscle. It presents a lipid fraction 14-fold as high as that of Longissimus dorsi $m$. (LD) taken from the same animal ( $p<0.05)$, the highest value reported so far. This was unequivocally observed by the histological evaluation. Proportionally more protein fraction and conversely less moisture were also observed in RB. Analysis of collagen and its crosslinking with hydroxylysylpyridinium (HP) showed there to be $22.9 \%$ more collagen and 14-fold as much HP in RB as in LD. Contrary to the expectations, the tenderness of fresh samples evaluated by Warner Bratzler shear force measurements led to values of 8.05 and 5.81 $k g f$ for $L D$ and $R B$, respectively ( $p<0.05)$. These results showed that the abundant fat in fresh $R B$ acted as a lubricant for the needle penetration, irrespective of the quantity and quality of collagen fibres present.
\end{abstract}

Key words: zebu breed, collagen, hydroxylysylpyridinium, meat tenderness, marbling fat

\section{INTRODUCTION}

There are approximately 180 million heads of beef cattle in Brazil; the majority is Bos indicus, which helps to make Brazil one of the major beefproducing countries in the world. The developed humpback muscle, popularly known as cupim in Brazil, is unique to the zebu breed. It can be approx. $1.0 \%$ of the total cold carcass in weight and is much appreciated barbecued by Brazilians.
It is believed that its biological origin was the necessity of the animal to have a supply of nutrients in order to resist long warm and dry season (Santiago, 1998) (Fig. 1). One of its characteristics is that, despite the visible presence of a high proportion of fat, it is relatively tough and to the best of our knowledge, there is no report available relating its chemical composition to its organoleptic qualities.

\footnotetext{
* Author for correspondence: massami.shimokomaki@pq.cnpq.br
} 
Meat texture sensation is dictated by several factors, including the amount of intramuscular fat, connective tissue, actomyosin complex, and its water holding capacity (Avery and Bailey, 1995). Collagen and its crosslinking are important factors to be considered (Shimokomaki et al., 1972, Coró et al. 2002). Nishimura et al. (1999) reported that abundant marbled intramuscular fat is the main factor affecting the meat texture of Japanese Black cattle. Earlier studies indicated that marbling degree accounted for 3 to $10.0 \%$ of the variation in texture in a relatively small amount of beef intramuscular fat (Tatum et al., 1980). In this paper, we describe the influence of lipid content and of collagen and its crosslinking on the texture of Rhomboideus $m$. hump muscle meat. L. dorsi $m$. from the same animals is included in the study for comparison sake.

\section{MATERIAL AND METHODS}

\section{Animals}

Six zebu breed (Bos indicus) animals (24 months old) fed native grasses raised at North Paraná state region, Brazil and slaughtered in a commercial abattoir (Jataizinho, PR, Brazil) were studied. The carcasses were kept refrigerated for 24 hours prior to analysis.

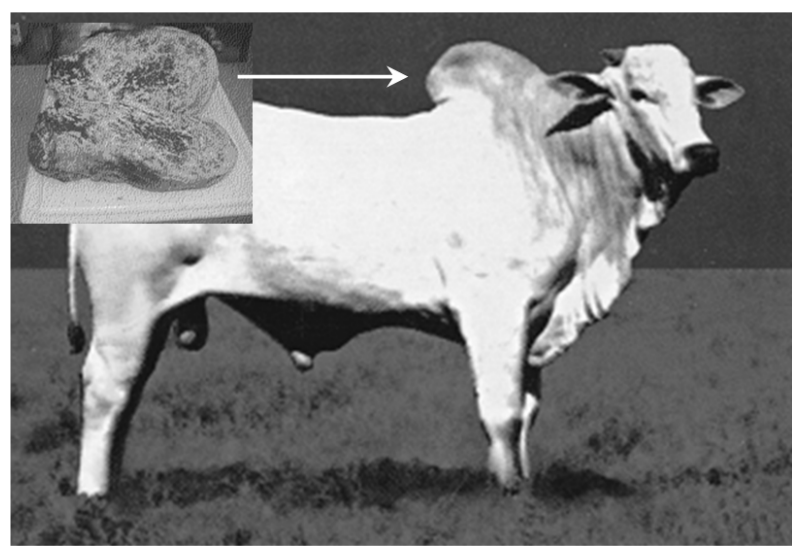

Figure 1 - Typical Nelore animals and the location of Rhomboideus $m$. The clear region of the muscle is fat and the brown one is muscle fibre.

\section{Samples}

Six samples of both Rhomboideus m. (RB) and Longissimus dorsi $m$. (LD) were excised from each carcass. Aponevrosis tissues were carefully removed by dissection and intramuscular samples were analysed.

\section{Basic chemical composition}

Moisture, ash, and protein concentrations were determined according to AOAC (1995). The lipid extraction was quantitatively measured by the Bligh and Dyer technique (1959).

\section{Determination of Collagen and Hydroxylysylpyridinium (HP) \\ Collagen was quantitatively evaluated by determining the amount of hydroxyproline (hypro) following Woessner technique (1961). Basically,}

$1.0 \mathrm{~g}$ of ground intramuscular sample was hydrolysed with distilled $6 \mathrm{~N} \mathrm{HCl}$ at $105^{\circ} \mathrm{C}$ for 18 h. Hydrolysate hypro concentration was determined by the reaction with pdimethylaminobenzaldehyde solution and colour intensity reading in spectrophotometer (Cintra 20, model GBC). The amount of collagen was determined by multiplying the colour intensity to 8.0 (Kolar, 1980). HP was analyzed by HPLC (Avery, et al., 1996). It consisted essentially in removing myofibrillar proteins with a $0.06 \mathrm{M} \mathrm{KCl}$ treatment, centrifugation, and the precipitate was collected and dialyzed against several distilled water changes and finally lyophilised. Amounts of $50 \mathrm{mg}$ of lyophilised samples were hydrolysed in $\mathrm{HCl} 6.0 \mathrm{~N}$ and non-crosslinking amino acids were initially separated on CF1 cellulose column as described in Skinner (1982) and adapted by Coro 
et al. (2002). After eluting the HP solution from the CF1 column with water, the samples were lyophilised and dissolved in buffer A $(5.0 \%$ acetonitrile, heptafluorobutyric acid, HFBA). HP was eluted from the column by applying a gradient solution of buffer B (pure acetonitrile, HFBA) on a Shimadzu HPLC model RF-535 with a Supelco reverse phase column. The location of HP signal on the chromatogram was confirmed with an HP standard. The HP standard curve was obtained by using HP concentrations from 0.25 to $10 \mathrm{pmol}$ considering collagen MW to be $3.38 \times 10^{5} \mathrm{~g}$ of collagen and 429.1985 $\mathrm{g}$ for $\mathrm{HP}$ as stated in Bosselman et al., (1995).

\section{Meat texture}

Texture was measured by Warner Bratzler shear force (WBSF) in an SMS Texture Analyser, TAXT2i model (Bouton et al., 1971). Before the measurement, samples (150-200g) were cooked in a vacuum-sealed plastic bag until the internal temperature reached $78-80^{\circ} \mathrm{C}$, cooled to $20^{\circ} \mathrm{C}$, and stored overnight at $4^{\circ} \mathrm{C}$. Subsequently, 50 meat cubes $\left(\right.$ ca. $1 \mathrm{~cm}^{3}$ ) were cut from each sample and texture was measured (Young et al., 1994; Coró et al., 2003).

\section{Light microscopy}

Meat samples were fixed in Bouin solution for $12 \mathrm{~h}$ at room temperature, dehydrated and included in parplast as described by Biscontini et al. (1996). Samples were cut at $5 \mu$ size and stained in HE solution and picrosirius to observe collagen fibre distribution (Junqueira et al., 1979). Samples were analysed by optical microscopy by Zeiss microscope, model Axiophot.

\section{Statistical analysis}

Results were processed using Statistica software package Statsoft ${ }^{\mathrm{TM}}$ (1995) and submitted to variance analysis and Tukey test in order to observe average differences.

\section{RESULTS}

\section{Proximate chemical composition:}

Table 1 shows the approximate chemical compositions of RB and LD muscles. These demonstrated a much higher incidence (12-15\%) of intramuscular fat in RB than in LD. Conversely, LD presented twice as much moisture and 1.7-fold as much protein fraction as RB (Table 1). These results suggested that hump meat was more marbled than LD, being even more than most Japanese Black cattle muscles (Zambayashi et al., 1995 ) and had as much as $20 \%$ extractable lipids, ranking it as the fattest muscle so far reported.

Table 1 - Approximate \% chemical composition of Rhomboideus m. (RB) and L. dorsi m. (LD) of 24-month old Bos indicus breed.

\begin{tabular}{ccc}
\hline & RB & LD \\
\hline Moisture & $36.70^{\mathrm{a}}( \pm 1.49)$ & $73.34^{\mathrm{b}}( \pm 1.77)$ \\
Ash & $0.99^{\mathrm{a}}( \pm 0.00)$ & $0.99^{\mathrm{a}}( \pm 0.00)$ \\
Lipid & $48.82^{\mathrm{a}}( \pm 6.80)$ & $3.39^{\mathrm{b}}( \pm 1.34)$ \\
Protein & $12.60^{\mathrm{a}}( \pm 2.70)$ & $21.18^{\mathrm{b}}( \pm 2.12)$ \\
\hline
\end{tabular}

${ }^{a, b}$ Within the same line means having different superscripts are significantly different $(p<0.05)$.

Collagen content: collagen crosslinking and texture measurement

Quantitative analyses of collagen, HP and texture of both muscles are shown in Table 2 .

Although RB presented $22.9 \%$ more collagen and particularly approximately 14 -fold as much crosslinked collagen as LD did, the latter was nearly 1.4-fold tough. These results were unexpected in absolute terms because the higher collagen values and crosslinking should lend a higher texture to the meat (Shimokomaki et al., 1972). One explanation lies in the higher level of marbling in $\mathrm{RB}$, which offers lower resistance in WBS measurement (Table 2). On the other hand, in practice, hump muscle meat is perceived as tougher than LD after cooking by Brazilian consumers, and hence, it calls for longer cooking or harsher conditions such as pressure cooking to prepare it. The measurement of meat texture of hump samples with very high fat content by WBS force is not reliable as the lipid content acts as a lubricant and enables the WB needle to move smoothly through the sample. Obviously, this effect was not found in LD as shown in Table 2. 
For most consumers, the texture sensation of meat prepared by common barbecue technique was due to the amounts of collagen and HP in meat (Table 2). From a practical cooking point of view, it is necessary to heat hump samples longer to break up collagen and its crosslinking. Results demonstrated that fresh Nellore hump muscle meat possessed a composition totally different from those of other beef skeletal muscles and that caution should be taken in measuring its tenderness and interpreting the results.

Table 2 - Quantitative analysis of collagen content (g/\%), Hydroxylysylpyridinium (HP) (mo/mol) of collagen, and Warner Bratzler shear force (WBS) texture measurement $(\mathrm{kg} / \mathrm{F})$ of Rhomboideus and L. dorsi muscles of 24-month old Bos indicus.

\begin{tabular}{cccc}
\hline Samples & Collagen & HP & WBS \\
\hline Rhomboideus $m$. & $12.40^{\mathrm{a}}( \pm 0.71)$ & $0.452^{\mathrm{a}}( \pm 0.25)$ & $5.81^{\mathrm{a}}( \pm 1.34)$ \\
L. dorsi $m$. & $9.56^{\mathrm{b}}( \pm 0.62)$ & $0.048^{\mathrm{b}}( \pm 0.015)$ & $7.98^{\mathrm{b}}( \pm 1.93)$ \\
\hline
\end{tabular}

${ }^{\mathrm{a}, \mathrm{b}}$ Within the same columns means having different superscripts are significantly different $(\mathrm{p}<0.05)$.

\section{Light microscopy studies}

Figures $2 \mathrm{~A}$ and $2 \mathrm{~B}$ show differences in the distribution of muscle $(\mathrm{M})$ and fat $(\mathrm{F})$ cells of LD and RB muscles. As quantitatively demonstrated in Table 1, there was far more $\mathrm{F}$ cells in LD than in RB muscles as expected. They show random distribution in LD in contrast to the localized areas of $\mathrm{F}$ and $\mathrm{M}$ cells in $\mathrm{RB}$.

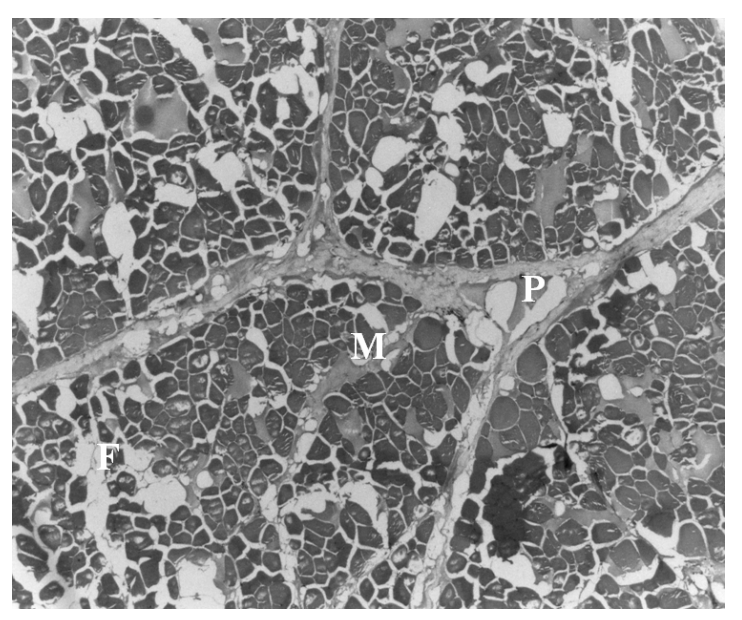

Figure 2A - Light micrograph of Bos indicus L. dorsi m. Note the distribution of fat (F) and muscle cells (M). P: Perymisium.x200.

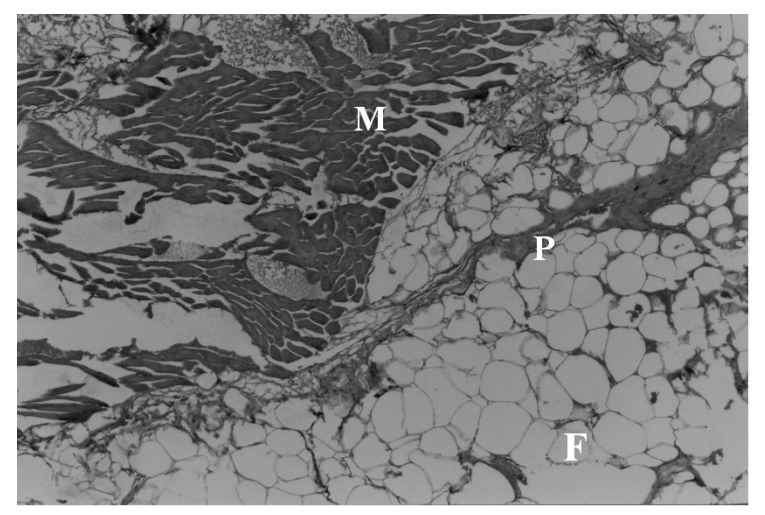

Figure 2B - Light micrograph of Bos indicus Rhomboideus $\mathrm{m}$. Note the higher distribution of fat cells (F) in relation to muscle cells. P: Perymisium. x200. 
The collagen fibres distribution at perymisium sheaths in both samples was also observed. Proximate chemical composition results demonstrated an incidence of intramuscular fat 1215 fold as high in RB as in LD. Present results indicated that the Nellore hump muscle meat presented a totally different composition from those of other beef skeletal muscles, having unique sensory characteristics due to its abundant fat content.

\section{RESUMO}

A composição química percentual aproximada do cupim m. Rhomboideus (RB) derivado de Nelore (Bos indicus) de 24 meses de idade mostrou ser um músculo diferenciado. Há uma maior fração de material lipídico em RB chegando a ser 14 vezes proporcionalmente maior em comparação ao $\mathrm{m}$. Longissimus dorsi (LD) $(\mathrm{p}<0,05)$ a maior quantidade de gordura relatada em amostras de carne em literatura científica. Esse fato foi também observado pela avaliação histológica. Há proporcionalmente maior concentração da fração protéica e menor quantidade de umidade em RB. O teor de colágeno foi de $22,9 \%$ mais concentrado em RB enquanto que a quantidade da sua ligação cruzada, hidroxilisilpiridinolina (HP) foi 14 vezes maior indicando que cupim seria mais rígido. Contrariando essa expectativa, a maciez da carne crua avaliada pelo texturômetro mostrou valores de 8.05 e $5.81 \mathrm{~kg} / \mathrm{F}$ para $\mathrm{LD}$ e RB, respectivamente $\quad(p<0.05)$. Tais resultados mostram que em músculo contendo abundante gordura esta funciona como lubrificante para a lamina penetrar sem muita resistência através do cupim a despeito dar quantidade e qualidade das fibras de colágeno.

\section{ACKNOWLEDGEMENTS}

The authors are grateful to Prof. A. J. Bailey (University of Bristol, UK) for providing a sample of hydroxylysylpyridinium (HP) standard. MM, $\mathrm{NES}$, and MS acknowledge $\mathrm{CNPq}$ research fellowships.

\section{REFERENCES}

AOAC Association of Official Analytical Chemistry (1995), Official methods of analysis of AOAC International.

Avery, N. C., Sims T. J., Warkup, C., Bailey, A. J. (1996), Collagen cross-linking in porcine $\mathrm{M}$. longissimus lumborum: absence of a relationship with variation in texture at pork weight. Meat Sci. 42, 355369.

Avery, N. C., Bailey, A. J. (1995), An efficient method for the isolation of intramuscular collagen. Meat Sci. 41, 97-100.

Bligh, E. G. and Dyer, W. J. (1959), A rapid method of total lipid extraction and purification. Can J Biochem. Physiol. 37, 911-917.

Biscontini, T. M. B., Shimokomaki, M., Ferreira, S. O. and Zorn, T. M. T. (1996), An ultrastructural observation on charquis, salted and intermediate moisture meat products. Meat Sci., 43, 351-358.

Bouton, P. E.; Harris, P. V.; Shorthose, W. R. (1971), Effect of ultimate $\mathrm{pH}$ upon the water - holding capacity and tenderness of mutton. J. Food Sci., 36, 35-439.

Bosselmann, A., Möller, C., Steinhardt, H., Kirchgessner, M. And Schwarz, F. J. (1995), Pyridinoline cross-links in bovine muscle collagen. $J$. Food Sci. 60, 953-958.

Coró, F. A. G.; Youssef, E. Y., Shimokomaki, M., (2002). Age related changes in poultry breast meat collagen pyridinoline and texture. J. Food Biochemistry. 26, 533-541.

Eyre, D. R. (1987), Collagen cross-linking amino acids. Methods in Enzymology, 144, 115-139.

Folch, J., Lees, M. and Sloanne S.G.H. (1957). A simple method for the isolation and purification of total lipid from animal tissues. J. Biol. Chem., 226, 497-509.

ISO - International Organization for Standardization. (1978), Animal and vegetable fats and oils preparation of methyl esters of fatty acids. Method ISSO 5509.

Junqueira L. C. U., Bignolas G, Brentani R. R. (1979), Picrosirius staining plus polarization microscopy, a specific method for collagen detection in tissue sections. Histochem. J. 11, 447-455.

Kolar, K. (1990), Colorimetric determination of hydroxyproline as measure of collagen content in meat and meat products: NMKL collaborative study. JAOAC 71, 54-57.

Nishimura, T., Hattori, A., Takahashi, K., (1999), Structural changes in intramuscular connective tissue during the fattening of Japanese Black Cattle: Effects of marbling on beef tenderization. J. Anim. Sci., 77, 93-104. 
Ruiz, M. R., Matsushita, M., Visentainer, J. V., Hernandez, J. A., A. Ribeiro, E. L., Shimokomaki, M., Reeves, J. J. and Souza, N. E. (2005), Proximate chemical composition and fatty acid profiles of Longissimus dorsi from pasture fed LHRH immunocastrated, castrated and intact Bos indicus bulls. South Africa J. Anim. Sci., 35, 13-18.

Santiago, A. A. (1998), O zebu na Índia, no Brasil e no mundo. Instituto Campineiro de Ensino Agrícola, Campinas.

Shimokomaki, M. Elsden, D. F. and Bailey, A. J. (1972), Meat tenderness: Age related changes in bovine intramuscular collagen. J. Food Sci. 37, 892896.

Skinner, S. J. M. (1982), Rapid method for the purification of the elastin cross-links, desmosine and isodesmosine. Journal of Chromatography, 229, 200204.
Statsoft (1995), Statistic for Windows v5.0 Statsoft Inc. Tulsa, USA.

Tatum, J. D. G. C., Smith, B. W. Berry, C. E. Murphey, F. L. Williams, and Z. L. Carpenter. (1980), Carcass characteristics, time on feed and cooked beef palatability attributes. J. Anim. Sci., 50, 833-840.

Young, O. A., Braggins, T. J., Barker, G. J. (1994), Pyridinoline in ovine intramuscular collagen. Meat Sci., 37, 297-303.

Woessner, J. F. (1961), The determination of hydroxyproline in tissue and protein samples containing small proportions of this aminoacid. Arch. Biochem. Biophys. 93, 440-447.

Received: March 30, 2006; Revised: January 30, 2007; Accepted: October 13, 2009. 